\title{
EVALUATION OF IN VITRO ANTIDIABETIC AND ANTI-INFLAMMATORY ACTIVITIES OF LEAVES EXTRACT OF BOEHMERIA RUGULOSA
}

\author{
ABHA SHUKLA, ANCHAL CHOUDHARY* \\ Department of Chemistry, Kanya Gurukula Campus, Gurukula Kangri Vishwavidyalaya, Haridwar, Uttarakhand, India. \\ Email: anchalkchoudhary@gmail.com
}

Received: 13 March 2018, Revised and Accepted: 21 May 2018

\section{ABSTRACT}

Objective: The objective of the study is to evaluate in vitro antidiabetic and anti-inflammatory activity of different extracts of leaves of Boehmeria rugulosa by different methods.

Methods: In vitro $\alpha$-glucose and $\alpha$-amylase were used for antidiabetic activity and lipoxygenase, and protein denaturation method of inhibition assays was used to measure anti-inflammatory activity. Successive extraction of leaves petroleum ether (PE), chloroform (CH), ethyl acetate (EA), acetone (AC), and ethanol (ETH) was performed, and extracts obtained from the extraction were applicable to these activities.

Results: The AC extract of leaves shows significantly in vitro antidiabetic activity, and AC has offered significant result $470.07 \pm 0.65 \mu \mathrm{g} / \mathrm{mL}$ in the inhibition of $\alpha$-glucosidase and also for $\alpha$-amylase assay $698.15 \pm 1.71 \mu \mathrm{g} / \mathrm{mL}$. Acarbose was used as standard. In lipoxidase method, AC had shown better results and in protein denaturation method EA shown the higher inhibition $(78.06 \pm 0.5 \mu \mathrm{g} / \mathrm{ml})$ than the other extracts. The standard drug diclofenac sodium also offered significant inhibition against lipoxidase enzyme method with $\mathrm{IC}_{50}$ value $21.76 \pm 1.29 \mu \mathrm{g} / \mathrm{mL}$.

Conclusion: These findings suggest that the AC and EA possess potent antidiabetic and anti-inflammatory activities in vitro conditions.

Keywords: Anti-inflammatory, Antidiabetic, Boehmeria rugulosa, Diclofenac sodium, Acarbose.

(C) 2018 The Authors. Published by Innovare Academic Sciences Pvt Ltd. This is an open access article under the CC BY license (http://creativecommons. org/licenses/by/4. 0/) DOI: http://dx.doi.org/10.22159/ajpcr.2018.v11i9.25906

\section{INTRODUCTION}

Boehmeria rugulosa belongs to the family Urticaceae, and it is found in tropical and subtropical region of Himalayan. The plant is widely used in traditional system of medicine for human health. Leaves extracts obtained with different solvents were contained polyphenols, tannins, saponins, carbohydrates, fatty acids, and various trace elements which are responsible for the various biological activities. Some isolated and identified phytochemicals from leaves have been demonstrated to own significant biological properties [1]. Diabetes mellitus (DM) is characterized by a group of chronic endocrine disorder in which the deficiency of insulin causes glucose to accumulate in the blood, leading to a group of metabolic diseases [2]. Currently, there is growing interest in herbal remedies due to the lesser side, low cost, and better response for the treatment of DM [3]. More than 400 plants worldwide have been documented as beneficial in the treatment of diabetes $[4,5]$.

The mechanism of the anti-inflammatory activity are shown by two different pathway. In the present study, plant extract shows the inhibition by protein denaturation method $[6,7]$. The mechanisms of inflammation which involve the metabolism of anachronic acid play an important role. It can be metabolized by the 5-lipoxygenase (5LOX) pathway to hydroperoxyeicosatetraenoic acids (HPETEs) and leukotrienes (LTs), which are important biologically active mediators in a variety of inflammatory events. In 5-LOX pathways, appropriate stimulation of neutrophils, anachronic acid is cleaved from membrane phospholipids and can be converted to LTs. Inhibition of 5-LOX leads to decreasing production of LTs. Furthermore, inflammatory processes also involve reactive oxygen species started by leukocyte activation. Therefore, antioxidant properties may provide important information about the potential activity of a drug on inflammatory processes [8].

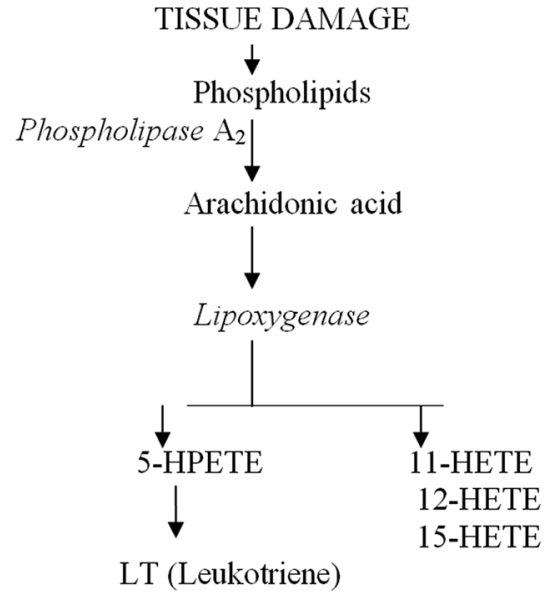

The lipoxygenase pathways of arachidonic acid catabolism designed above. Algogenic compounds are shown in bold type and enzymes which are shown in italics. HETE: Hydroxyeicosatetraenoic acids, HPETE: Hydroperoxyeicosatetraenoic acids, LT: Leukotriene.

A survey of literature indicated no research work has been conducted to evaluate the anti-inflammatory and antidiabetic potential of $B$. rugulosa leaves by in vitro method. The present study concerns the determination of anti-inflammatory activity of by inhibition of albumin denaturation and anti-lipoxygenase activity, however, antidiabetic activity by $\alpha$-amylase and $\alpha$-glycosidase methods. 


\section{METHODS}

\section{Standards and reagents}

Brovine serum albumin, lipoxidase enzyme, and linoleic acid were obtained from Sigma-Aldrich, Tris buffer (Merck), p-Nitrophenyl- $\alpha$-Dglucopyranoside (SRL Pvt., Ltd.), $\alpha$-amylase (SRL Pvt., Ltd.,), dimethyl superoxide (DMSO) (Merck), 3,5-dinitrosalicylic acid (DNSA) (SRL Pvt., Ltd.,), $\alpha$-glucosidase (SRL Pvt Ltd); and acarbose (Bayer India Limited), sodium carbonate (CDH), petroleum ether (PE) (Merck), ethanol (ETH) (Merck), ethyl acetate (EA) (Merck), and acetone (AC) (Merck) were purchased. All other solvents and chemical used were analytical grade.

\section{Collection of plant material}

The bark of plant $B$. rugulosa was collected from the Rishikesh region. Voucher specimens have been put in the Herbarium of the Botanical Survey of India, Dehradun, in November 2015, with accession no. 115901. A voucher specimen has been deposited in medicinal plants Herbarium Department of Chemistry, Kanya Gurukula Campus, Gurukula Kangri Vishwavidyalaya, to registry no. 1/4. The plant materials were washed, dried in shade and ground to powder, and stored in polythene bags for further use.

\section{Preparation of extracts and phytochemical screening}

Plant extraction was done by the Soxhlet extraction process with different solvents. Phytochemical screening was carried out by standards of analytic methods [9].

\section{Antidiabetic activity}

In vitro methods employed in antidiabetic activity of each extract by $\alpha$-amylase and $\alpha$-glycosidase inhibitory assay.

\section{$\alpha$-amylase inhibition activity}

The $\alpha$-amylase inhibitory activity of extracts was performed using DNSA method with a slight modification $[10,11]$.

A total of $1 \mathrm{ml}(1-1000 \mu \mathrm{g} / \mathrm{ml})$ of test samples and standard drug (100$1000 \mu \mathrm{g} / \mathrm{ml}$ ) were added to $1 \mathrm{ml}$ of $20 \mathrm{mM}$ phosphate buffer (pH 6.9) containing $\alpha$-amylase ( $3 \mathrm{mg} / \mathrm{ml}$ ) solution and were incubated at $37^{\circ} \mathrm{C}$ for $30 \mathrm{~min}$. After these, $1 \mathrm{ml}$ of a $1 \%$ starch solution in $20 \mathrm{mM}$ phosphate buffers ( $\mathrm{pH}$ 6.9) was added to each tube. The reaction mixtures were then incubated at $37^{\circ} \mathrm{C}$ for $15 \mathrm{~min}$. The reaction was stopped with $1 \mathrm{ml}$ of DNSA color reagent. The test tubes were then incubated in a boiling water bath for $5 \mathrm{~min}$, and cooled to room temperature. The reaction mixture was then diluted after adding $9 \mathrm{ml}$ distilled water, and absorbance was measured at $540 \mathrm{~nm}$.

For correcting background absorbance (absorbance due to extracts or standard), the enzyme was substituted for $1 \mathrm{ml}$ buffer solution with similar test procedure. The $\alpha$-amylase inhibitory activity was obtained by the equation.

$$
\underset{\alpha \text {-amylase inhibitory }}{\text { activity }(\% \text { inhibition })}=\frac{\left[\left(\mathrm{AC}^{+}-\mathrm{AC}^{-}\right)-(\mathrm{AS}-\mathrm{AB})\right]}{\left(\mathrm{AC}^{+}-\mathrm{AC}^{-}\right)} \times 100
$$

Where AC+ represents absorbance of pure control having 100\% enzyme activity (DMSO and enzyme), AC- symbolizes absorbance of blank for pure control having 0\% enzyme activity (DMSO and buffer), AS represents absorbance of sample or standard (sample/standard and enzyme), and $\mathrm{AB}$ symbolizes for background absorbance due to sample and standard (sample/standard and buffer). $\mathrm{IC}_{50}$ of each extract and standard acarbose was calculated by the graphical method by plotting $\%$ inhibition versus concentration.

\section{$\alpha$-glucosidase inhibition activity}

The inhibitory activity was determined in accordance with according to Andrade-Cetto et al. [12] with a minor modification [13].
Briefly, $1 \mathrm{ml}$ of each solution of different concentrations $(1-5000 \mu \mathrm{g} / \mathrm{ml})$ of extracts or standard acarbose in DMSO was incubated with $1 \mathrm{ml}$ of $\alpha$-glucosidase ( $1 \mathrm{U} / \mathrm{ml}$ in $100 \mathrm{mM}$ phosphate buffer $\mathrm{pH}$ 6.8) for $30 \mathrm{~min}$ at $37^{\circ} \mathrm{C}$. The enzyme reaction is started by adding $1 \mathrm{ml}$ of p-nitrophenyl$\alpha$-dglucopyranoside in $100 \mathrm{mM}$ phosphate buffer ( $\mathrm{pH} 6.8$ ). The reaction mixtures were then incubated for $15 \mathrm{~min}$ at $37^{\circ} \mathrm{C}$. The reaction was stopped by adding $4 \mathrm{ml} 0.5 \mathrm{M}$ Tris buffer. The absorbance was taken by UV-VIS spectrophotometer (Agilent Technologies cary-60) at $410 \mathrm{~nm}$. For correcting background absorbance, the enzyme was replaced by $1 \mathrm{ml}$ buffer solution with similar test proceduree. The \% inhibition and $\mathrm{IC}_{50}$ were calculated in a similar way as mentioned in $\alpha$-amylase activityy. Earlier $0.1 \mathrm{M} \mathrm{NaOH}$ was used to stop the reaction. Each test was performed three times, and the mean absorption was used to calculate the percentage $\alpha$-glucosidase inhibition. The control samples were also prepared accordingly without any plant extracts and were compared with the test samples containing the plant extracts prepared with different solvents.

$$
\begin{aligned}
& \alpha-\text { glucosidase inhibitory } \\
& \operatorname{activity}(\% \text { Inhibition })
\end{aligned}=\frac{\left[\left(\mathrm{AC}^{+}-\mathrm{AC}^{-}\right)-(\mathrm{AS}-\mathrm{AB})\right]}{\left(\mathrm{AC}^{+}-\mathrm{AC}^{-}\right)} \times 100
$$

\section{Anti-inflammatory activity}

\section{Inhibition of albumin denaturation}

The anti-inflammatory activity of a plant extract was studied using inhibition of albumin denaturation technique which was studied according to Mizushima and Kobayashi [14] and Sakat et al. [15] followed with minor modifications. The reaction mixture $(0.5 \mathrm{ml}$; $\mathrm{pH}$ 6.3) consisted of $0.45 \mathrm{ml}$ of bovine serum albumin (5\% aqueous solution) and $0.05 \mathrm{ml}$ of distilled water. $\mathrm{pH}$ was adjusted at $6.3 \mathrm{using}$ a small amount of $1 \mathrm{~N} \mathrm{HCl}$. Different concentrations of plant extract (50$1000 \mu \mathrm{g} / \mathrm{ml}$ ) were added to the reaction mixture and were incubated at $37^{\circ} \mathrm{C}$ for $20 \mathrm{~min}$ and then heated at $60^{\circ} \mathrm{C}$ for $10 \mathrm{~min}$, and after cooling the samples, $2.5 \mathrm{~mL}$ of phosphate buffer saline was added. Turbidity was measured spectrophotometrically at $660 \mathrm{~nm}$. The percentage inhibition of protein denaturation was calculated as follows:

$$
\text { Percentage inhibition }(\%)=\frac{\left(\mathrm{Abs}_{\mathrm{Control}} \mathrm{Abs}_{\text {sample }}\right)}{\mathrm{Abs} \text { Control }} \times 100
$$

\section{Anti-lipoxygenase assay}

Anti-lipoxygenase assay was studied using linoleic acid as substrate and lipoxidase as an enzyme. The test solution was dissolved in $0.25 \mathrm{ml}$ of $2 \mathrm{M}$ borate buffer $\mathrm{pH} 9.0$ and added $0.25 \mathrm{ml}$ of lipoxidase enzyme solution $(20,000 \mathrm{U} / \mathrm{ml})$ and incubated for $5 \mathrm{~min}$. at $25^{\circ} \mathrm{C}$. After which, $1 \mathrm{ml}$ of linoleic acid solution $(0.6 \mathrm{mM})$ was added, mixed well, and absorbance was measured at $234 \mathrm{~nm}$. Diclofenac was used as the reference standard [16]. Percentage inhibition of lipoxygenase assay was calculated using the following formula:

$$
\text { Percent inhibition }(\%)=\frac{\left(\mathrm{A}_{\text {control }^{-}} \mathrm{A}_{\text {test }}\right)}{\mathrm{A}_{\text {control }}} \times 100
$$

Where $A_{\text {control }}$ is the absorbance of the control reaction and $A_{\text {test }}$ is the absorbance of the control reaction to extract.

\section{RESULTS AND DISCUSSION}

\section{Antidiabetic activity}

\section{$\alpha$-Amylase inhibition activity}

The in vitro $\alpha$-amylase inhibitory activity of $B$. rugulosa leaves extracts compared with acarbose is illustrated in Table 1 . All the extracts had shown signifying results. Acarbose showed percentage alpha-amylase inhibition of in varying concentration from $(1-1000 \mu \mathrm{g} / \mathrm{ml})$ with an $\mathrm{IC}_{50}$. Lower $\mathrm{IC}_{50}$ value corresponds to greater potential and better therapeutic efficacy. $\mathrm{AC}$ extract is taken into consideration in the highest alpha-amylase inhibitory activity. It can be viewed as an excellent inhibitory activity. 
$\alpha$-glucosidase inhibitory activity

The in vitro $\alpha$-glucosidase inhibitory activity of $B$. rugulosa leaves extracts compared with acarbose is illustrated in Table 2.

The $\alpha$-glucosidase inhibition on changing the concentration of each extract helps in an estimation of $\mathrm{IC}_{50}$ value of each extract as well as standard acarbose [17]. All the extracts showed inhibitory effects toward $\alpha$-glucosidase. The AC extract had the highest inhibition activity $(470.070 .65 \mu \mathrm{g} / \mathrm{ml})$ while ETH had the lowest inhibition (1152.27 $0.37 \mu \mathrm{g} / \mathrm{ml})$.

In the present study, leaves extracts were evaluated for antidiabetic activity and acarbose was used as a standard reference. The finding of the results reveals that the AC shows good results followed by the EA.

\section{Anti-inflammatory activity}

\section{Inhibition of albumin denaturation}

Protein denaturation is a process whereby proteins lose their tertiary structure and secondary structure by application of external stress, such as strong acid or base, a concentrated inorganic salt, and an organic solvent or heat. Most biological proteins lose their biological function when denatured. Denaturation of proteins is a well-documented cause of inflammation. As part of the investigation of the mechanism of the anti-inflammatory activity, ability of plant extract to inhibit protein denaturation was examined [18]. It had successfully inhibiting heatinduced albumin denaturation. Maximum inhibition of $78.061 \%$ was measured at $500 \mu \mathrm{g} / \mathrm{ml}$. Diclofenac, a standard anti-inflammation drug, showed the maximum inhibition $94.20 \%$ at the concentration $500 \mu \mathrm{g} / \mathrm{ml}$ in Table 3 .

Comparison of all extract inhibition with the standard is shown in the Fig. 1 in and their \% inhibition is shown in Table 3 for comparison

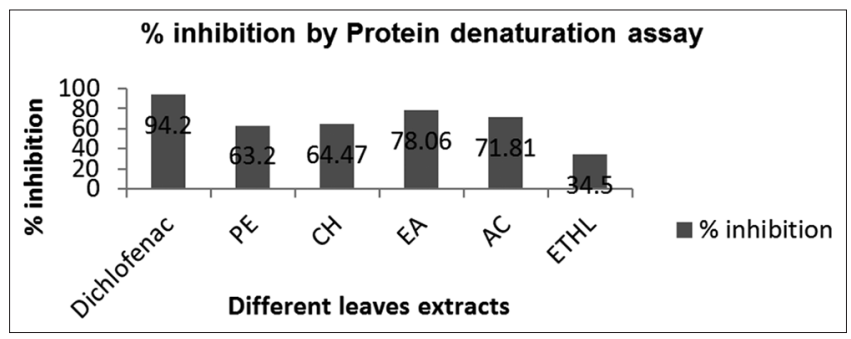

Fig. 1: Comparision of leaves extract with standards

Table 1: IC $_{50}$ value of leaves extracts for $\alpha$-amylase inhibition assay

\begin{tabular}{ll}
\hline Extracts/Standards & IC $_{50}$ value \\
\hline Acarbose & $617.23 \pm 0.15$ \\
Petroleum ether & ND \\
Chloroform & $1310.21 \pm 0.46$ \\
Ethyl acetate & $820.34 \pm 1.3$ \\
Acetone & $698.15 \pm 1.71$ \\
Ethanol & $497.68 \pm 1.12$ \\
\hline
\end{tabular}

ND: Not detectable

Table 2: $\mathrm{IC}_{50}$ value of leaves extract for $\alpha$-glucosidase inhibition assay

\begin{tabular}{ll}
\hline Extracts/Standards & IC $_{50}$ value \\
\hline Acarbose & $358.42 \pm 1.52$ \\
Petroleum ether & $\mathrm{ND}$ \\
Chloroform & $875.89 \pm 0.93$ \\
Ethyl acetate & $624.84 \pm 0.78$ \\
Acetone & $470.07 \pm 0.65$ \\
Ethanol & $1152.27 \pm 0.37$ \\
\hline
\end{tabular}

ND: Not detectable purpose. The EA extract of leaves indicated the highest inhibition compared to other extracts from inhibition $78.06 \mu \mathrm{g} / \mathrm{ml}$.

\section{Anti-lipoxygenase activity}

The establishment of new in vitro test systems has stimulated the screening of plants aiming to find the development of new drugs [19]. $\mathrm{IC}_{50}$ values are given in the Table 4 .

It is expected to result to comparison with the standard diclofenac sodium with $\mathrm{IC}_{50}$ value $21.76 \mu \mathrm{g} / \mathrm{ml}$. AC extract shows better results than the other extracts, which shows their potential in inflammation. The 5-LOX leads to the formation of biologically active lipoxins. Whereas, it is leading the formation of 5, 6-epoxy LTs, which are responsible for inflammation. In the present study, leaves extracts show the significant consequences for in vitro anti-inflammatory activity. In protein denaturation assay EA, extract shows better results which were followed by AC. Now, EA extract shows comparable inhibition with reference standards followed by AC.

\section{CONCLUSION}

In the present study, leaves extracts indicate the significant antidiabetic and anti-inflammatory activities by in vitro $\alpha$-glucosidase and alphaamylase assay for antidiabetic and heat-induced protein denaturation, and 5-LOX enzyme methods apply for anti-inflammatory activity. Our results showed that $\mathrm{AC}$ extract of leaves was batter for antidiabetic and anti-inflammatory activities followed by the EA extracts by in vitro conditions. These findings suggest that $\mathrm{AC}$ and EA were more potent for these activities. However, further studies currently undergo a process for different parts of this plant for biological activities.

\section{ACKNOWLEDGMENT}

We wish to acknowledge the Department of Kanya Gurukula Campus, Gurukula Kangri University, Haridwar, for providing the research facilities for in vitro studies in the present investigation.

\section{AUTHORS' CONTRIBUTION}

Anchal - conceptualization of paper and compilation full manuscript.

Abha Shukla - Reviewing and checking of the manuscript in improving the level of the manuscript.

\section{CONFLICTS OF INTEREST}

There are no conflicts of interest.

Table 3: Effect of leaves extracts on heat-induced protein denaturation treatment concentration $(500 \mu \mathrm{g} / \mathrm{ml})$ and absorbance at $660 \mathrm{~nm}$

\begin{tabular}{lll}
\hline Extracts/standards & Concentration $(\mu \mathrm{g} / \mathrm{ml})$ & \% inhibition \\
\hline Diclofenac sodium & 500 & $94.20 \pm 0.65$ \\
Petroleum ether & 500 & $63.20 \pm 1.11$ \\
Chloroform & 500 & $64.47 \pm 1.36$ \\
Ethyl acetate & 500 & $78.06 \pm 0.5$ \\
Acetone & 500 & $71.81 \pm 1.72$ \\
Ethanol & 500 & $34.50 \pm 1.52$ \\
\hline
\end{tabular}

Table 4: $\mathrm{IC}_{50}$ value of leaves extracts with standards for lipoxidase inhibition assay

\begin{tabular}{ll}
\hline Extracts/standards & IC $_{50}$ values \\
\hline Diclofenac sodium & $21.76 \pm 1.29$ \\
Petroleum ether & $\mathrm{ND}$ \\
Chloroform & $254.46 \pm 0.7$ \\
Ethyl acetate & $249.89 \pm 5.97$ \\
Acetone & $89.07 \pm 0.85$ \\
Ethanol & $151.27 \pm 1.2$ \\
\hline ND: Not detectable &
\end{tabular}




\section{REFERENCES}

1. Semwal DK, Rawat U, Semwal R, Singh R, Krishan P, Singh GJ. Chemical constituents from the leaves Of Boehmeria rugulosa with antidiabetic and antimicrobial activities. J Asian Nat Prod Res 2009; 11:1045-55.

2. Das P, Devi PV, Yasmine Y. Assessment of in vitro anti-diabetic activity of Ficus glomerata Merina. Pharm Lett 2016;8:267-72.

3. Day C, Bailey CJ. Hypoglycemic agents from traditional plant treatments for diabetes. Int Ind Biotech 1998;50:5-8.

4. Gray AM, Flatt PR. Nature's own pharmacy: The diabetes perspective. Proc Nutr Soc 1997;56:507-17.

5. Swanston-Flatt SK, Flatt PR, Day C, Bailey CJ. Traditional dietary adjuncts for the treatment of diabetes mellitus. Proc Nutr Soc 1991;50:641-50.

6. Leelaprakash G, Dass SM. In-vitro anti-inflammatory activity of methanol extract of Enicostemma axillare. Int J Drug Dev Res 2010;3:189-96.

7. Ingle PV, Patel DM. C-reactive protein in various disease condition - an overview. Asian J Pharm Clin Res 2011;4:9-13.

8. Anoop MV, Bindu AR. In-vitro anti-inflammatory activity studies on Syzygium zeylanicum (L.) DC Leaves. Int J Pharm Res Rev 2015;4:18-27.

9. Anchal C, Shukla A, Shukla RK, Tyagi R. Evaluation of Antioxidant and antidiabetic capacity of plant Boehmeria rugulosa bark. Int J Chemtech Res 2017;10:324-32.

10. Hansawasdi C, Kawabata J, Kasai T. Alpha amylase inhibitiors from Roselle (Hibiscus sabdariffa). Biosci Biotechnol Biochem
2000;64:1041-3.

11. Rengasamy S, Thangaprakasam U. Isolation, screening and determination of a-amylase activity from Marine streptomyces species. Int J Pharm Pharm Sci 2018;10:122-7.

12. Andrade-Cetto A, Becerra-Jimenez J, Cardenas-Vazquez R. Alphaglucosidase inhibiting activity of some Mexican plants used in the treatment of Typa 2 diabetes. J Ethnopharmacol 2008;116:27-32.

13. Li D, Ni JM. Preliminary study of an alpha-glucosidase inhibition from the roots and stems of polygonatum sibiricum Red. Asian J Tradit Med 2008;3:179-85.

14. Mizushima Y, Kobayashi M. Interaction of anti-inflammatory drugs with serum proteins, especially with some biologically active proteins. J Pharm Pharmacol 1968;20:169-73.

15. Sakat S, Juvekar AR, Gambhire MN. In vitro antioxidant and antiinflammatory activity of methanol extract of Oxalis corniculata Linn. Int J Pharm Pharm Sci 2010;2:146-55.

16. Cashman JN. The mechanisms of action of NSAIDs in analgesia. Drugs 1996;52:13-23.

17. Singh N, Gupta AK, Juyal V, Deepak P, Gahlot M. Phytochemical screening and blood glucose level lowering effect of Bergenia ligulata root extracts. J Nat Remedies 2011;11:19-23.

18. Reddenna P, Whelan J, Maddipati KR, Reddy CC. Purification of arachidonate 5-LOX from potato tubers. Methods Enzymol 1990;187:268-77.

19. Shinde UA, Kulkarni KR, Phadke AS, Nair AM, Dikshit VJ, Mungantiwar AA, et al. Mast cell stabilizing and lipoxygenase inhibitory activity of Cedrus deodara Roxb loud wood oil. Indian J Exp Biol 1999;37:258-61. 